\title{
LEAN HEALTHCARE IN HOSPITAL EMERGENCY DEPARTMENT. CASE STUDY
}

\author{
Mira LISIECKA-BIEŁANOWICZ ${ }^{1}$, Krystyna LISIECKA ${ }^{2 *}$ \\ ${ }^{1}$ Medical University of Warsaw, Faculty of Health Sciences, Department of the Prevention of Environmental \\ Hazards and Allergology, Warsaw, Poland; mira.bielanowicz@wum.edu.pl, ORCID: 000-0001-8251-0546 \\ ${ }^{2}$ Katowice School of Economics (Górnośląska Wyższa Szkoła Handlowa w Katowicach), Poland; \\ krystyna.lisiecka@gwsh.pl, ORCID: 0000-0001-5061-5757 \\ * Correspondence author
}

Purpose: The purpose of the study was to identify waste in the selected health care facility, the types and sources of events that trigger it, and to indicate possibilities to shorten time in which patients wait for help.

Material and Methods: The case study was an Emergency Department located in the Province of Silesia. The Issue is many hour queues at the Emergency Departments.

Results: Time to receive medical treatment is too long. Not only are high-risk patients being taken care of, but also patients who did not manage to visit their family doctor (General Practitioner - GP).

Conclusions: The authoresses formulated a thesis that there are possibilities to shorten the waiting time for medical services at the Emergency Department.

Keywords: Lean Healthcare, waste, triage, emergency department, life-threatening medical emergencies.

\section{Introduction}

Managers of healthcare sector institutions search for sources of more rational management of funds, including not being wasteful. They use various methods of managing processes of shaping the quality of the provided services and build organisation improvement on the model of VBHCB (Value Based Health Care Benefit) (Porter, and Teisberg, 2006; Porter, 2010; Ciećko, Bandurska, Zarzeczna-Baran, 2018). One of these is Lean Management (LM). LM enables standardization of processes by identifying and then eliminating waste between the processes, thereby improving the productivity of the whole organisation (Lisiecka, and Burka, 2016). In order to identify and minimise waste, the following principles in the LM implementation process should be applied: value identification, Value Stream Map (VSM), 
flow, pulling and improvement (Womack, and Jones, 2008, 2010). The "king" of these rules, according to B. Oppenheim, is the principle of Pull. It is about "getting the results of work from the position which is before my position" (Oppenheim, 2006, p. 8-20).

The starting point for the implementation of Lean principles is the process approach (Lisiecka-Biełanowicz, 2016, p. 52). It is expressed in the development of a process map which shows the stream of creating LM values. The assumptions and principles of Lean in Healthcare (LH) can be applied in any healthcare institution, regardless of its ownership structure. Using LH tools allows for improving work organisation and reducing the amount of time lost, i.a. for such reasons as: incorrectly identified medical documentation, material, or medical tool, ill-conceived arrangement of equipment, rooms, including specialist laboratories. The challenge for managers of healthcare institutions is the personalised nature of health services, complexity of the treatment process, use of advanced technologies, information asymmetry, and the need to ensure service standards which are measured by, i.a. the number of adverse events (Walshe, and Smith, 2011, p. 27). An adverse event is damage caused during treatment or as a result of it, unrelated to the natural course of the disease, the patient's health condition, or an increased risk of its occurrence. The number of adverse events provides information about the quality and safety of services proffered by the institution. The effectiveness of activities is demonstrated by achieving the intended clinical effect, and economic efficiency is shown by the ratio of expenditures to the results obtained (Zestaw standardów akredytacyjnych, 2009).

Adverse events existing in the therapeutic processes, including medical errors, can be divided into two groups:

- the first group is irreversible errors - errors with irreversible consequences (e.g. clinical),

- the second group of adverse events is reversible errors. A reversible error is understood as any failure during the implementation of the planned action or the enaction of an incorrect action plan "A" (Kohn, Corringan, Donaldon, 2000). Understanding the cause of a given reversible error is important since it requires specifying in detail whether the occurrence of a specific adverse clinical event could have been prevented by, e.g., planning and then failing to implement this plan.

Research in this area has shown that the majority of medical errors appearing in entities of the healthcare sector are reversible errors (about 70-80\%), which after their detection are left without any formal report or mention (Opolski, Waśniewski, 2011, p. 143). It is important to detect medical errors early enough in order for their consequences to be corrected/reversed. Figure 1 shows the types of adverse events that may occur during the provision of health services (Kohn, Corringan, Donaldon, 2000; Walshe, Smith, 2011). 


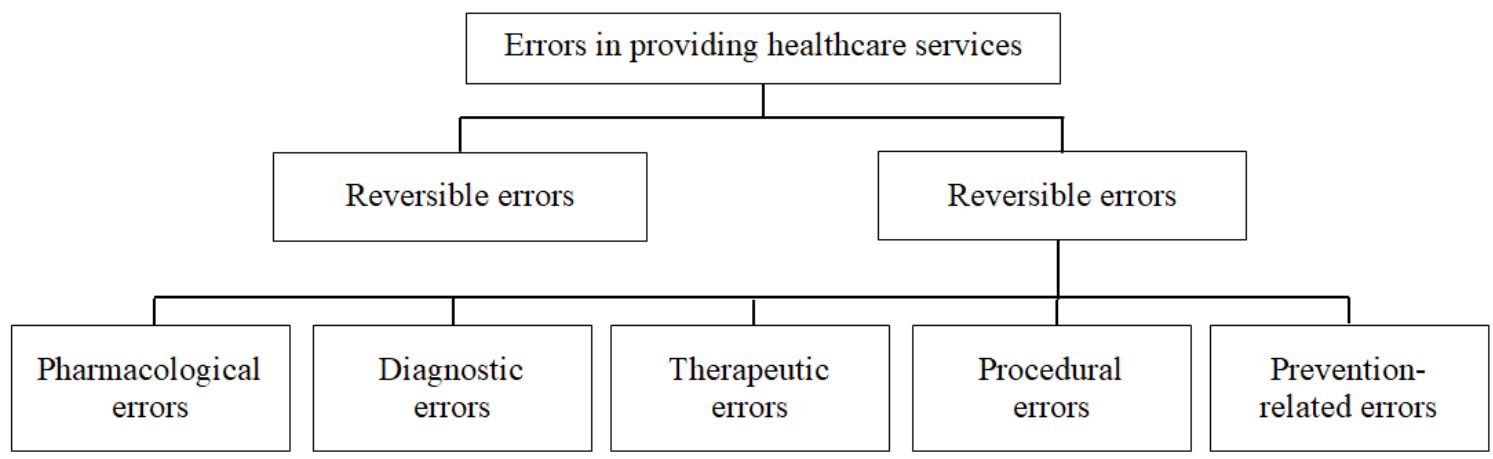

Figure 1. Types of adverse events that can occur during the provision of healthcare services. Source: Own elaboration based on Kohn L.T., Corringan J., Donaldon M.S., To err is human: Building a safer health system, Institute of Medicine (U.S.) Committee on Quality of Health Care in America, DC, National Academy Press, Washington 2000.

The first step in dealing with adverse events should be to identify them. Each organisation which registers adverse events should develop a list of monitored events in order to facilitate their recording and to give a possibility of identifying new threats. It is important to determine when and where the event took place and who participated in the activities.

A model for managing adverse events and modules of the sphere of managing adverse events in healthcare institutions (Stauss, Schoeler, 2003) is as follows (Figure 2):

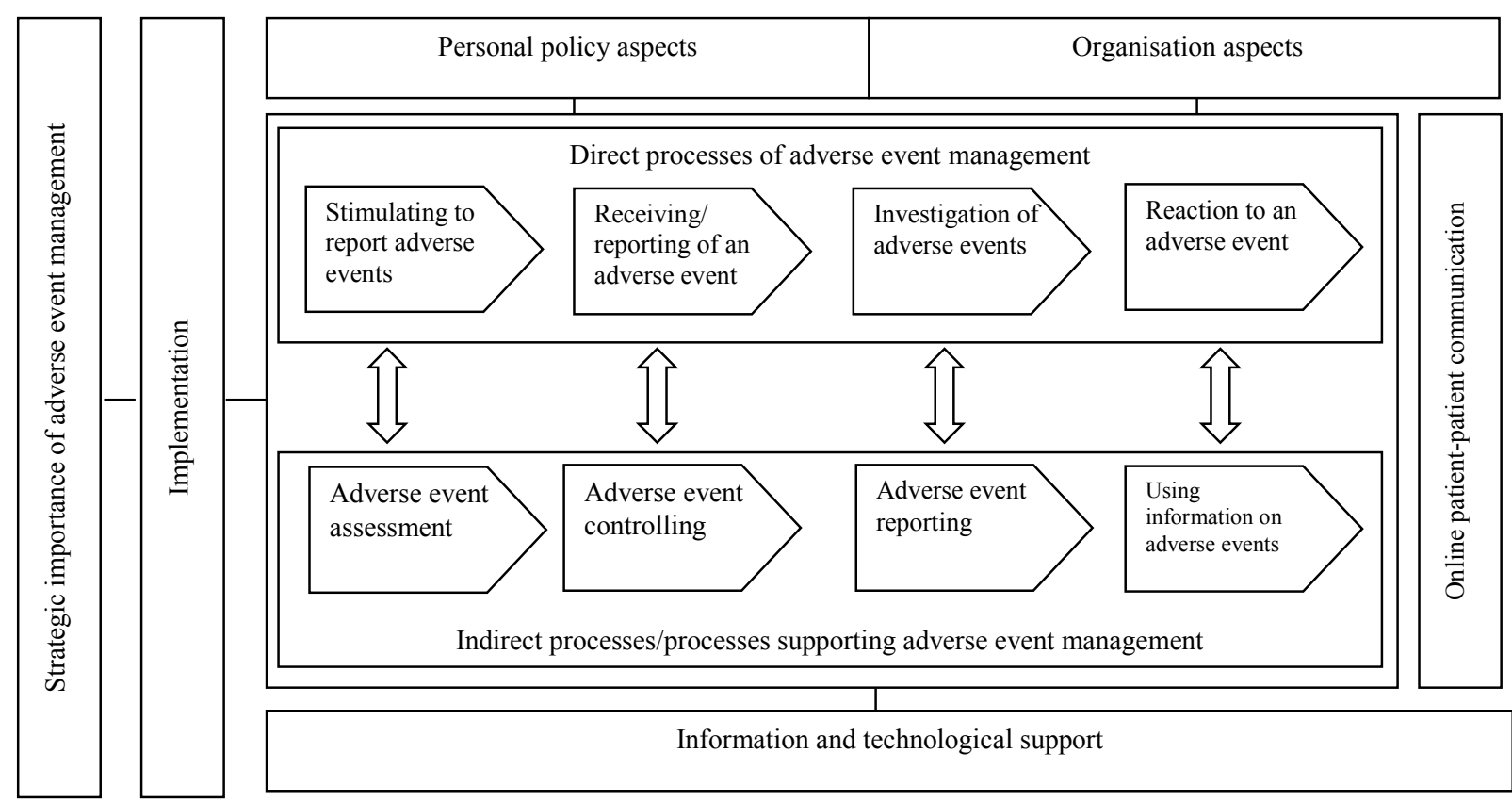

Figure 2. Modules of adverse event management. Source: elaborated based on Stauss B., Schoeler A., Beschwerdemanagement Excellence. State-of-the-Art und Herausforderungen der Beschwerdemanagement-Praxis in Deutschland, Verlag Dr. Th. Gabler GmbH, Wiesbaden 2003, p. 27. 
These modules are: encouraging the reporting of adverse events and putting into place methods of how to receive these events, their investigation, response, assessment, controlling, reporting adverse events, and using information about them. These modules are coupled, and information and technology support the ability to communicate with the sender.

\section{Material and Method}

The entity covered by the study was an Emergency Department (ED). The ED is an organisational unit of a hospital and the National Emergency Medical System created to provide healthcare services to a person in a medical emergency (Regulation of the Minister of Health, 2011. The reason for choosing this particular entity for research is because of the critical position of the ED (input) in the process of admitting a patient to a hospital in a medical emergency, and the inadequate structuring of Emergency Departments (EDs) in the country, the low decision-making or even its lack as regards the undertaken diagnostic and therapeutic activities at the ED, as well as the lack of due diligence in adhering to procedures, as well as the insufficient and incorrect financing of the EDs - which causes inefficiency within these Departments.

The aim of the study was to identify waste in the ED Department of a hospital located in the Silesia Province and to determine the types and sources of adverse events causing this in order to provide mitigation.

The study was carried out in two stages. The first stage included a study using a survey questionnaire among randomly selected ED patients. Herein, 73 patients - both women and men of different ages - were included in the study. The second part of the study was based on an expert face-to-face interview with a group of experts composed of persons employed at the ED. This stage enabled conducting an analysis, as well as making a detailed presentation of the types and sources of events affecting the patient's total waiting time for the provision of services at the ED, including adverse events. By sharing their knowledge and experience, the experts pointed out problems not visible from the perspective of patients staying at the EDs. 


\section{Research results and discussion}

In the opinion of $99 \%$ of all respondents - patients at the ED - the most commonly present adverse event is the excessive waiting time for the provision of medical services. The expert face-to-face interview was the basis for developing a Process Chart for proceeding with an ED patient. The reason for creating the Process Chart was the desire to identify all stages that the ED patient goes through - from admitting the patient to the Department, to discharging them. This made it possible to take into account those places and moments in which the patient was awaiting continuation of medical activities. Figure 3 shows the process of proceeding with the patient at the ED.

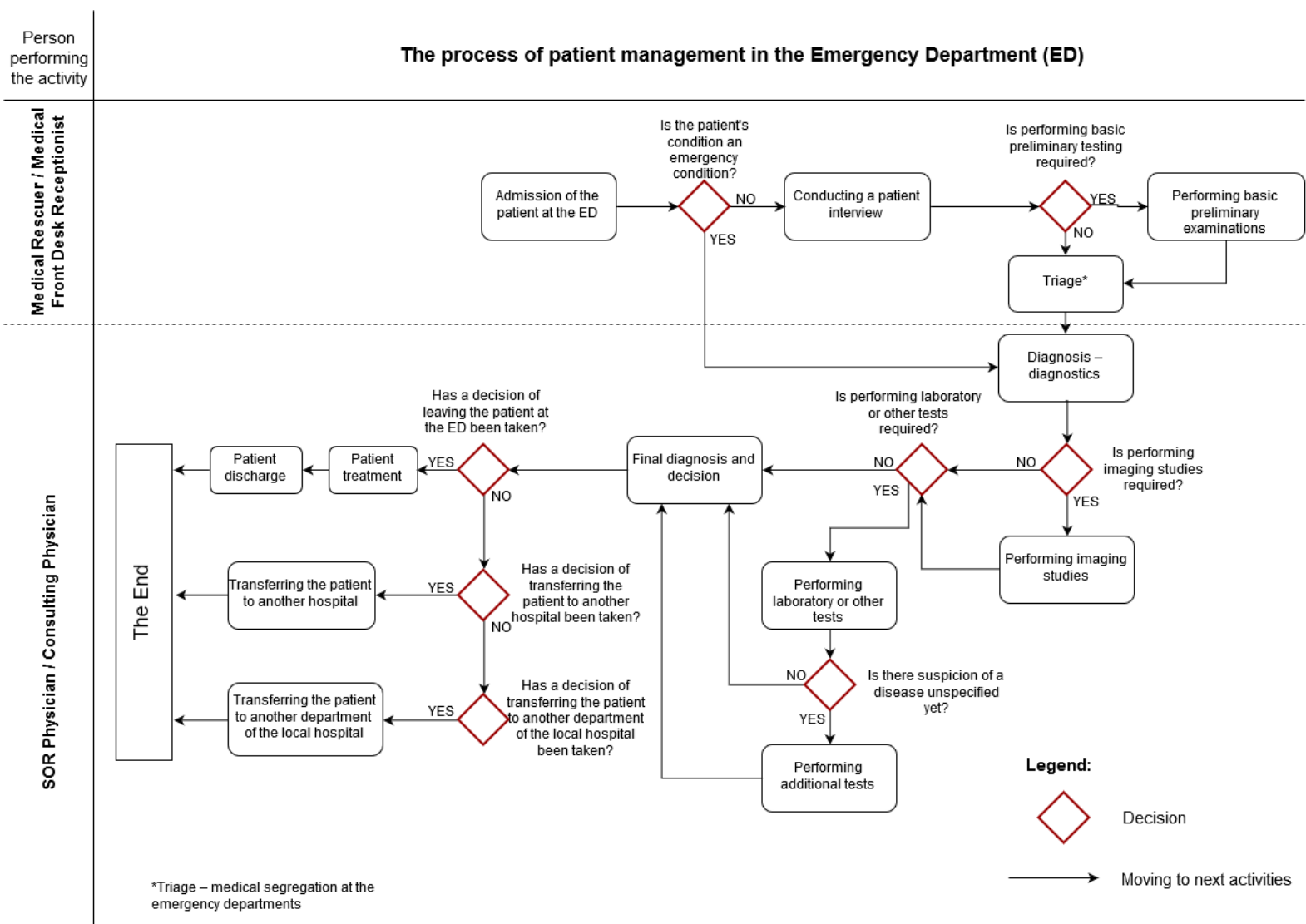

Figure 3. Process of patient management at the ED. Source: Elaboration prepared by Aleksandra Janus in her master's theses under guidance of Krystyna Lisiecka. 


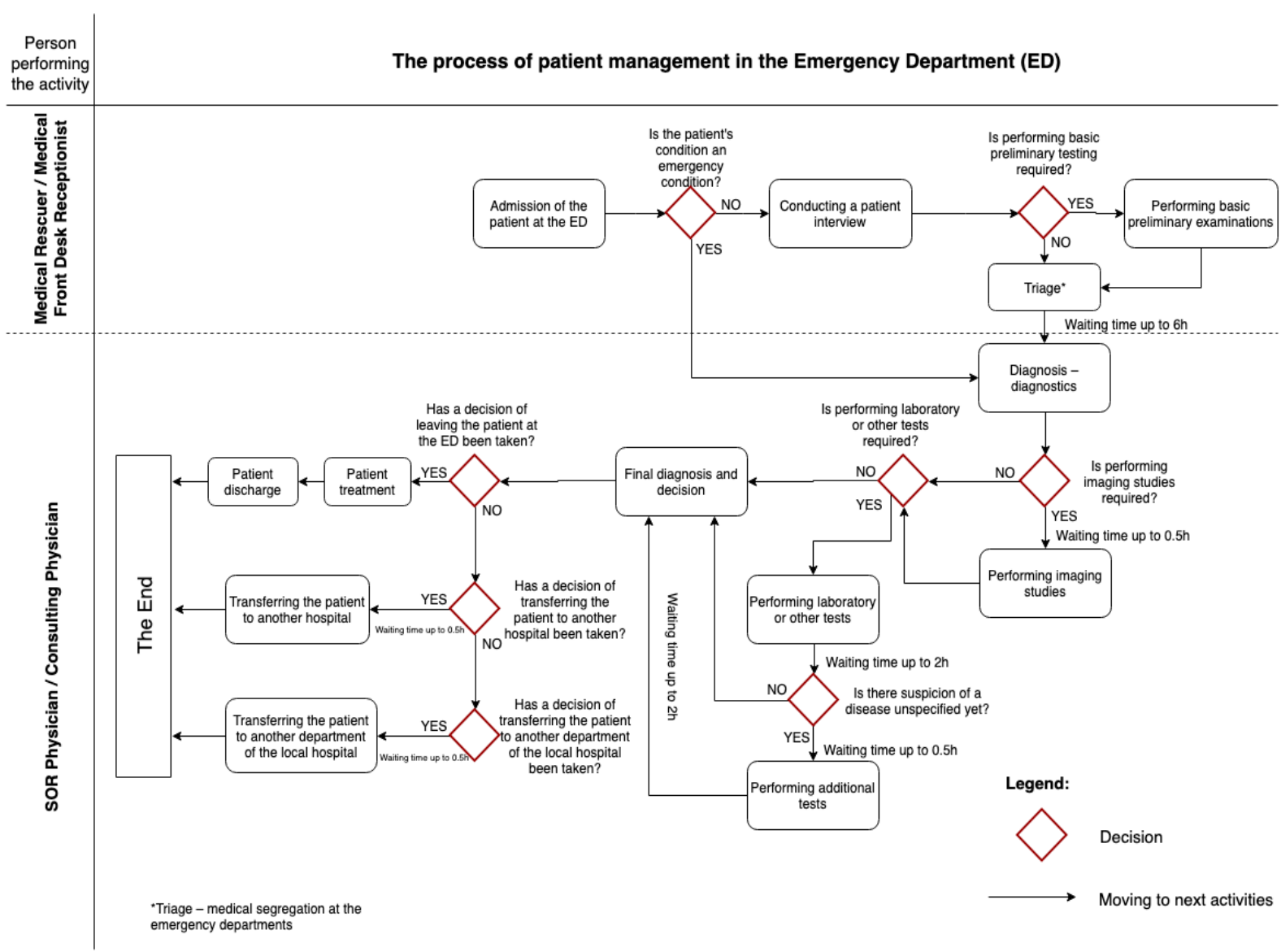

Figure 4. Process of patient management at the ED - taking into account the time criterion - patient's waiting time for the provision of service. Source: Elaboration prepared by Aleksandra Janus in her master's theses under guidance of Krystyna Lisiecka.

Figure 4 illustrates the process of patient management in the ER, including the patient's waiting time at various stages.

The first stage of the patient's waiting time at the ED takes place after conducting the triage. This waiting time is a result of qualifying the patient to a given group of patients. It consists in determining the order in which patients are admitted by an ED physician in accordance with the standards of medical selection, the so-called triage ${ }^{1}$.

Triage is a kind of management subsystem that takes into account medical risk. It serves to provide safe division of the patients' condition into groups and the flow of patients in situations of the department's overcrowding.

This procedure - consisting in sorting the patients who are waiting - aims to determine to what extent their lives and health are at risk.

Patients can be classified into three groups: red, patients require immediate medical action (red band), the yellow group, patient for whom waiting time for admission can take up to one hour (yellow band), and the white group - it consists of patients who have not been qualified to any of the above-mentioned groups, while the patient's waiting time in this group may be up to six hours (white band).

\footnotetext{
${ }^{1}$ The word triage comes from French and means segregating, sorting.
} 
The second stage of the patient's waiting time during their stay at the ED occurs after the initial diagnosis resulting in the decision to perform imaging studies. The patients await the imaging studies for approximately 30 minutes on average.

The third stage of waiting occurs between performing laboratory tests and obtaining information about their results - up to approximately two hours. In the event of high specifics of the tests connected with e.g. repeated material sampling at various intervals, the waiting time may increase up to six hours. The waiting time before and after the implementation of the recommended additional examinations (e.g. additional imaging studies, laboratory tests, etc.) is similar.

The last identified stage of the patient's waiting in the diagnostic process within the ED occurs following the final diagnosis and decision made by the ED physician (with the possible support of a consulting physician). This patient's waiting time is connected with the decision to transfer them to another hospital department or to another hospital. The patient's waiting time is a direct result of the need for ED personnel to organise transport in order to relocate the patient. The waiting time is on average up to approximately 30 minutes. Patients belonging to the yellow and white group can wait longer - even up to as long as ten hours.

Responsibility for the occurrence of waste, i.e. the Muda phenomenon, i.e. for the appearance or extension of the patient's waiting time for medical services, is largely the result of adverse events occurring in the activities of the Emergency Room.

As a result of a direct interview with an expert group, typical types of adverse events in the Emergency Department under study have been established (Table 1). They do not exhaust the scope and type of adverse events that may potentially occur in the ED's activities.

Table 1.

Sources of adverse events causing the MUDA phenomenon at the Emergency Department

\begin{tabular}{|c|c|c|c|c|}
\hline Waiting & $\begin{array}{c}\text { Defective } \\
\text { movement }\end{array}$ & $\begin{array}{l}\text { Deficiency/defecti } \\
\text { veness }\end{array}$ & Transport & $\begin{array}{c}\text { Unnecessary data } \\
\text { processing }\end{array}$ \\
\hline $\begin{array}{l}\text { Patient's too long } \\
\text { waiting time for the } \\
\text { diagnosis } \\
\text { (up to approx. } 6 \mathrm{~h} \text { ) }\end{array}$ & $\begin{array}{l}\text { Defectiveness of } \\
\text { the process of } \\
\text { transferring } \\
\text { materials to the } \\
\text { laboratory }\end{array}$ & $\begin{array}{c}\text { Lack of sufficient } \\
\text { number of } \\
\text { personnel }\end{array}$ & $\begin{array}{l}\text { Adverse events } \\
\text { associated with the } \\
\text { transport of the } \\
\text { patient to the } \\
\text { department or to } \\
\text { a place outside the } \\
\text { hospital (occurs } \\
\text { with an increased } \\
\text { number of patients } \\
\text { at the ED) }\end{array}$ & $\begin{array}{l}\text { Entering the same } \\
\text { data again in } \\
\text { different medical } \\
\text { documents created } \\
\text { in an electronic } \\
\text { version }\end{array}$ \\
\hline $\begin{array}{l}\text { Patient's too long } \\
\text { waiting time for the } \\
\text { examination } \\
\text { (up to approx. } \\
0.5 \mathrm{~h} \text { ) }\end{array}$ & & $\begin{array}{c}\text { Equipment } \\
\text { defectiveness } \\
\text { (regular } \\
\text { defectiveness) }\end{array}$ & & \\
\hline
\end{tabular}


Cont. table 1.

\begin{tabular}{|c|c|}
\hline $\begin{array}{l}\text { Patient's too long } \\
\text { waiting time for the } \\
\text { lab test results (up } \\
\text { to approx. 2h) }\end{array}$ & $\begin{array}{c}\text { Too long } \\
\text { sterilisation time } \\
\text { for medical } \\
\text { equipment due to } \\
\text { insufficient staff } \\
\text { (waiting time up to } \\
5 \text { days) }\end{array}$ \\
\hline $\begin{array}{l}\text { Too long waiting } \\
\text { time for the } \\
\text { patent's } \\
\text { transportation (up } \\
\text { to approx. 2h) }\end{array}$ & $\begin{array}{l}\text { Adverse events } \\
\text { resulting from } \\
\text { incorrect } \\
\text { information flow }\end{array}$ \\
\hline
\end{tabular}

Source: own elaboration.

The most common source of adverse events is organisational errors connected with staffing shortages, diagnostic equipment defectiveness and defectiveness of actions conducted (human factor); these generate or extend the patient's waiting time for service provisions. In addition, they generate waste in the form of the ED personnel's waiting time for the results of the activities. Table 2 presents adverse events spotted and identified, as well as the generated Muda phenomenon.

Table 2.

The impact of adverse events at the ED on the phenomenon of Muda generation in the form of the appearance or extension of the patient's waiting time

\begin{tabular}{|c|l|}
\hline \multicolumn{1}{|c|}{ Adverse event } \\
\hline Lack of sufficient number of personnel
\end{tabular}

Source: own elaboration.

The listed types of adverse events can be described as reversible errors, i.e. not directly generating a clinical error. The length of the patient's waiting after a triage is closely associated with the length of time spent on helping another patient. 
Eliminating or reducing the patient's total waiting time (total waiting after making the initial diagnosis) will shorten the waiting time for the next patient before making the initial diagnosis. This means that already with the second patient admitted after introducing the changes aimed at eliminating the identified Muda phenomenon - the patient's waiting time reduction will be noticeable. This will be possible owing to the elimination of waiting for the patient's transport twice - the first related to transporting for an imaging test (approx. 0.5 hours), the second related to transporting to another department/to another hospital (approx. 0.5 hours). Eliminating the inconvenience during the transfer of biological materials for testing will shorten the waiting time for the results of lab tests (currently approx. 2 hours) to about 1.5 hours. In the event of the need to undergo two laboratory tests or an additional test - the patient gains another 0.5 hour.

Summing up, the patient management process from initial diagnosis to discharge can be shortened by approximately 2 hours on average. Early termination of the patient care process (by 2 hours) will enable shortening the waiting time for the initial diagnosis of the next patient also by 2 hours.

This means that already the second patient admitted after the implementation of the changes eliminating or limiting the identified Muda phenomena will wait in total for approximately 4 hours less than the patient admitted before taking the proposed improvement actions.

\section{Summary of the conducted research}

Lean in Healthcare (LH) is a method which inspires to apply actions aiming at identifying and minimising waste in a healthcare institution by Value Stream Mapping (VSM). Thinking in the spirit of Lean requires looking for waste in between the processes.

The conducted research has proved that already the next (second) patient admitted to the ED after the implementation of improvement actions impacting upon the Muda phenomenon, will have a shorter wait than the ED patient admitted before undertaking the proposed ventures. If it is not possible to take actions related to the "waiting" areas discussed, it will be appropriate to implement other measures having an impact on the Muda phenomenon. Every improvement action, e.g. in the area of accessibility to diagnostic equipment (through the introduction of reliable technical reviews of the equipment or efficient organisation of the sterilisation process) or "doubling" the number of hospital staff at the Emergency Department (where the incurred increase in the costs of wages may pay off) will shorten the patient's total waiting time at the ED. The above-mentioned proposals require - which should be highlighted - shaping of the Lean culture among all of the ED department employees. 


\section{Acknowledgments}

The authors thank Aleksandra Janus who graduated from University of Economics in Katowice for collecting the data in the HED.

\section{References}

1. Ciećko, E., Bandurska, M., Zarzeczna-Baran (2018). Value based healthcare - czy Polska jest gotowa na rewolucję w zakresie finansowania świadczeń? Polski Przeglad Nauk o Zdrowiu, Gdański Uniwersytet Medyczny, 3(56), DOI: https://doi.org/10.20883/ppnoz.

2. Kohn, L.T., Corringan, J., Donaldon, M.S. (2000). To err is human: Building a safer health system. Washington: Institute of Medicine (U.S.) Committee on Quality of Health Care in America, DC, National Academy Press.

3. Lisiecka-Biełanowicz, M. (2016). Zarzadzanie jakościa relacji w organizacjach ochrony zdrowia. Warszawa: Wydawnictwo Difin.

4. Lisiecka, K., Burka, I. (2016). Lean Service w teorii i praktyce. Katowice: Wydawnictwo Uniwersytetu Ekonomicznego.

5. Master's theses of Aleksandra Janus under guidance of Krystyna Lisiecka.

6. Opolski, K., Waśniewski, K. (2011). Zarządzanie jakościa i ryzykiem w usługach zdrowotnych. Warszawa: CeDeWu.pl Sp. z o.o.

7. Oppenheim, B. (2006). Lean jako metoda myślenia - rozmowa z Bohdanem Oppenheimem. Zarządzanie Jakościa, 3(5),. pp. 8-20.

8. Porter, M.E. (2010). What is Value in Health Care? The New England Journal of Medicine, Perspective.

9. Porter, M.E., Teisberg, E.O. (2006). Redefining Health Care: creating value-based competition on results. Massachusetts, Boston: Harvard Busiess School Press.

10. Regulation of the Minister of Health dated 3 November, 2011 on the Emergency Department. Journal of Laws (2011, no. 237, item 1420).

11. Stauss, B., Schoeler, A. (2003). Beschwerdemanagement Excellence. State-of-the-Art und Herausforderungen der Beschwerdemanagement-Praxis in Deutschland. Wiesbaden: Verlag Dr. Th. Gabler GmbH.

12. Womack, J.P., Jones, D.T. (2010). Szczupłe rozwiązania, czyli jak przedsiębiorstwa i ich klienci moga pomnażać korzyści ze wzajemnej współpracy stosujac zasady lean management. Wrocław: LEI Polska.

13. Womack, J.P., Jones, D.T. (2008). Lean thinking - szczupłe myślenie. Eliminowanie marnotrawstwa i tworzenie wartości w przedsiębiorstwie. Wrocław: ProdPress.com. 
14. Walshe, K., Smith, J. (ed.) (2011). Zarządzanie w opiece zdrowotnej. Warszawa: Wolters Kluwer Polska Sp. z o.o.

15. Zestaw standardów akredytacyjnych (2009). Centrum Monitorowania Jakości w Ochronie Zdrowia. Kraków. 